\title{
Prediction of Acute Kidney Injury among ST- Elevation Myocardial Infarction Patients Treated with Primary Percutaneous Intervention by Hemoglobin Level and Left Ventricular Function
}

\author{
SALMA M. EL-SHOKAFY, M.Sc.; MAGDY M. EL-MASRY, M.D.; EHAB A. HAMDY, M.D. and \\ AYMAN A. EL-SHEIKH, M.D. \\ The Department of Cardiovascular Medicine, Faculty of Medicine, Tanta University, Tanta, Egypt
}

\begin{abstract}
Background: Among patients with ST-segment Elevation Myocardial Infarction (STEMI) undergoing primary Percutaneous Coronary Intervention (PCI), worsening of renal function resulting in Acute Kidney Injury (AKI) is a frequent complication known to be associated with adverse outcomes. Also, anemia on admission is associated with an increased risk for (AKI). The relation between echocardiographic parameters of Left Ventricular (LV) function and the risk of AKI among patients with STEMI undergoing PCI is still controversial.
\end{abstract}

Aim of the Study: Detection of the relationship between hemoglobin level and LV systolic and diastolic function as a predictors for developing AKI after primary PCI in patients with STEMI.

Methods: A prospective observational cohort study conducted from June 2016 to June 2017, at Cardiovascular Medicine Department, Tanta University Hospitals in Gharbia Governorate, Egypt. The study enrolled 38 consecutive adult patients of both genders who were diagnosed with definite STEMI within 12 hours from the time of symptoms onset and were treated by PCI who developed AKI after the procedure. The study population ( 38 patients) was then subdivided according to severity of renal impairment according to creatinine clearance $(\mathrm{Cr} \mathrm{cl})$ into two groups:

Group I: Those who developed severe renal impairment with $\mathrm{Cr} . \mathrm{cl} \leq 30 \mathrm{ml} / \mathrm{min}$ (17 patients).

Group II: Those who developed mild to moderate renal impairment with Cr.cl $\geq 30 \mathrm{ml} / \mathrm{min}$ (21 patients).

They were subjected to full clinical examination, laboratory investigation including serum creatinine $(\mathrm{sCr})$ level that was determined on hospital admission, before primary PCI, and at least once a day during the cardiac Intensive Care Unit stay, complete blood count with special attention to Hemoglobin $(\mathrm{Hb})$ level at hospital admission before primary PCI. All patients underwent a screening echocardiography within three days of admission, measurement of LV systolic function was performed using the commercially available machine

Correspondence to: Dr. Salma M. El-Shokafy, The Department of Cardiovascular Medicine, Faculty of Medicine, Tanta University, Tanta, Egypt
(Vivid 7, GE Medical System, Horten, Norway) with a 3.5$\mathrm{MHz}$ transducer. LV systolic function was assessed using Mmode in parasternal long axis view.

Results: Group I patients were older $(70.65 \pm 10.36$ years vs $57.43 \pm 12.09$ years, $p=0.001$ ), but there was no statistacillay significant difference between both groups for risk factors, smoking, dyslipidemia, diabetes, time to reperfusion, addiction, site of infarction or Killip's classification; but there was more prevelance of prior MI in Group I than Group II. There was a statistically significant difference between both groups as regard $\mathrm{Hb}$ level $(10.65 \pm 0.996 \mathrm{gm} / \mathrm{dl}$ vs $11.62 \pm 1.396 \mathrm{gm} / \mathrm{dl}, p=$ $0.017)$, $\mathrm{EF}(40.18 \pm 7.40 \%$ vs $48.67 \pm 8.05 \%, p=0.002), \mathrm{Cr} \mathrm{cl}$ ( $26.35 \pm 2.18 \mathrm{ml} / \mathrm{min}$ vs $39.10 \pm 5.61 \mathrm{ml} / \mathrm{min}, p=0.001)$, $\mathrm{sCr}$ on admission $(1.36 \pm 0.21 \mathrm{ml} / \mathrm{dl}$ vs $1.06 \pm 0.20 \mathrm{ml} / \mathrm{dl}, p=0.001)$, peak $\mathrm{sCr}(2.08 \pm 0.32 \mathrm{ml} / \mathrm{dl}$ vs $1.79 \pm 0.32 \mathrm{ml} / \mathrm{dl}, p=0.010)$ and $\mathrm{s} . \mathrm{Cr}$ level at discharge $(1.55 \pm 0.21 \mathrm{ml} / \mathrm{dl}$ vs $1.36 \pm 0.18 \mathrm{ml} / \mathrm{dl}, p=$ 0.004).

Conclusion: Older ages, previous history of myocardial infarction, TIMI flow after PCI, anemia on admission, level of serum creatinine on admission, creatinine clearance and impaired systolic function of left ventricle were strongly statistically different with developing AKI and related to its severity, while no significant statistical difference could be found as regard gender, smoking, addiction, diabetes, dyslipidemia, Killip classification, time to reperfusion, or site of infarction with incidence of developing AKI.

Key Words: Acute kidney injury - Percutaneous coronary intervention - Ejection fraction percentage $-\mathrm{Hb}$ level.

\section{Introduction}

WORLDWIDE, acute ST-segment Myocardial Infarction (STEMI) is one of the most important cardiovascular diseases that increase risk of morbidity and mortality [1]

The primary goal in management of acute STE$\mathrm{MI}$ is reperfusion therapy with intravenous fibrinolysis or primary Percutaneous Intervention (PCI) [2], which is the preferred strategy, if it is performed 
on time by experienced personnel. However; it still has some side effects [2].

Acute Kidney Injury (AKI) is a frequent complication among patients who undergo PCI shown to be associated with adverse outcomes [3-6]. Other important factors among this specific patient population includes an adverse hemodynamic state resulting in reduced renal perfusion, as well as other metabolic factors [7-9].

Some studies specifically demonstrated that low Ejection Fraction (EF) $<30 \%$ to $40 \%$ is an independent predictor of $\mathrm{AKI}$ in patients with $\mathrm{CHF}$ [10-12].

Anemia is a common finding known to have a decrimental effect on the outcome of STEMI [13,14] Previous studies have shown that anemia increases the risk of contrast-induced nephropathy in patient undergoing primary percutaneous intervention. Admission Hemoglobin ( $\mathrm{Hb}$ ) level was shown to be a predictor of in-hospital mortality among STEMI patients who underwent primary PCI [15]

It is well known that patients with an eGFR $<60 \mathrm{~mL} / \mathrm{min} / 1.73 \mathrm{~m}^{2}$ are more likely to have anemia and that prevalence and severity of anemia increase with declining renal function [16].

\section{Patients and Methods}

The study was conducted at the Department of Cardiovascular Medicine, Tanta University Hospital in Gharbia Governorate, Egypt, during the period between June 2016 to June 2017. It was carried out on 38 patients diagnosed definitively with STEMI and treated with primary PCI who developed contrast induced nephropathy after the procedure. An informed consent was taken from all participants.

Patients included in this study fulfilled the following criteria:

Patients admitted to the cardiac Intensive Care Unit with STEMI who underwent primary PCI within $12 \mathrm{~h}$ from symptom onset or between 12 and $24 \mathrm{~h}$ with evidence of continuing ischemia who developed contrast induced nephropathy post procedure.

\section{Exclusion criteria were:}

- Patients who were treated either conservatively or by thrombolysis.

- Patients whose final diagnosis on discharge was other than STEMI (e.g., myocarditis).
- Patients who died within 24 hours of admission because we presumed there was insufficient time for AKI to occur.

- Patients requiring chronic peritoneal dialysis or hemodialysis treatment.

- Patients without a pre procedure serum creatinine level.

- Patient with cardiogenic shock at time of presentation.

All included patients were subjected to detailed:

- History taking; (personal history-risk factors: Hypertension (HTN), smoking, addiction, Diabetes Mellitus (DM), chronic kidney disease-past history of premature coronary artery disease-past drug history of nephrotoxic drugs- family history for coronary artery disease).

- Clinical examination: Vital signs: e.g.: Heart rate, blood pressure, signs of heart failure/hemodynamic instability.

- Local cardiac examination.

- Twelve leads surface ECG: Routine 12-lead ECG was done for the patients to detect changes suggestive of STEMI.

- Venous sampling for laboratory data including:

A- Biomarkers of myocardial injury (troponin and $\mathrm{CKMB}$ ).

B- Complete blood count with special attention to $\mathrm{Hb}$ level at hospital admission before primary PCI. Anemia was defined as hemoglobin level $<12$ $\mathrm{g} / \mathrm{dL}$ in females and $<13 \mathrm{~g} / \mathrm{dL}$ in males according to World Health Organization criteria [17]

C- Serum creatinine $(\mathrm{sCr})$ level was determined on hospital admission, before primary PCI, and at least once a daily during the cardiac Intensive Care Unit stay and was available for all analyzed patients.

D- Creatinine clearance is calculated by the following formula: CreatClear $=\operatorname{sex} *((140$-age $) /$ $($ SerumCreat $)) *($ Weight/72) [18]

- Primary percutaneous intervention for Infarct Related Artery (IRA).

All included patients were subjected to primary PCI for the Infarct Related Artery (IRA) according to the ESC guidelines. Coronary angiography was performed under local anesthesia from the femoral approach according to the standard technique. Reperfusion success was assessed according to TIMI blood flow grade, and (IRA) was identified according to the culprit lesion on the basis of the infarct location on the admission ECG, and the 
angiographic findings (target vessel, lesion characteristics). The Choice of stents (bare-metal stent or drug-eluting stent) was left to the operator's discretion. The success of primary PCI was defined as achievement of the TIMI flow of the infarct related artery to grade III.

- Echocardiography: Within three days of admission, measurement of Left Ventricular (LV) systolic function was performed using the commercially available machine (Vivid 7, GE Medical System, Horten, Norway) with a 3.5-MHz transducer. LV systolic function is assessed using Simpson's method in the apical $4 \&$ apical 2 views and $\mathrm{M}$-mode in parasternal long axis view by directing the M-mode cursor across the midLV.

Statistical presentation and analysis of the present study was conducted, using the mean, Standard Deviation (SD) and Chi-square test by SPSS Version 20. Numerical data was presented as mean and Standard Deviation (SD), and categorical data was presented as number and percentage. For comparison Chi-square test was used for variables, and independent student ' $t$ ' test for numerical variables. The level of significance was adopted at $p<0.05$.

Subjects were informed about the purpose and procedure of the study and benefits of sharing in it. Ethical considerations of the study were carried out according to that of Declaration of Helsinki.

\section{Results}

The present study was conducted in Cardiology Department, Faculty of Medicine Tanta University. It was carried out on 38 adult patients of both genders diagnosed definitively with acute kidney injury after having primary $\mathrm{PCI}$ as revascularization strategy for STEMI, within 12 hours from the time of symptoms onset. The study was conducted from June 2016 to June 2017.

The study population was subdivided into two groups:

Group I: Those who developed severe renal impairment with Cr.cl $\leq 30 \mathrm{ml} / \mathrm{min}$ (17 patients).

Group II: Those who developed mild to moderate renal impairment with $\mathrm{Cr} . \mathrm{cl} \geq 30 \mathrm{ml} / \mathrm{min}$ (21 patients).

In the study we examined the relationship between patient characteristics, factors in initial clinical evaluation of the patients with prediction of occurrence of acute kidney injury and its severity.
- Age:

In Group I, the age ranged from 50 to 85 years with mean \pm SD age $70.65 \pm 10.36$ years and in Group II, it ranged from 38 to 82 years with mean \pm SD age $57.43 \pm 12.09$ years. There was significant difference among studied groups regarding age ( $p$ $<0.001)$ (Table 1).

- Gender:

Among the study population $68.40 \%$ of the patients were males and $31.60 \%$ were females. There was no statistically significant difference among studied groups regarding gender (Table 1).

\section{- Clinical charactaristics and risk factors among both study groups:}

There was no statistically significant difference between both groups as regard diabetes, hypertension, dyslipidemia, obesity, smoking or addiction, but there was a statistically significant difference between both study groups as regard history of prior MI $(p<0.05)$ (Tables 2,3).

\section{- Site of infarction:}

In Group I, 3 patients (17.7\%) had anterior MI, 10 patients $(58.8 \%)$ had inferior MI and $4(23.5 \%)$ patients had multiple infarction site. In Group II, 5 patient $(23.8 \%)$ had anterior MI, 13 patients $(61.9 \%)$ had inferior MI and 3 patients (14.3\%) had multiple infarction site. There was no statistically significant difference between the two groups as regard infarction site $(p=0.557)$ (Table 4).

\section{- Time to reperfusion and contrast volume used in both study groups:}

There was no significant difference as regard wether time to reperfusion $(67.94 \pm 26.04 \mathrm{~min}$ vs $57.14 \pm 24.11 \mathrm{~min})$ or contrast volume $(288.24 \pm 33.21$ $\mathrm{ml}$ vs $285.71 \pm 82.37 \mathrm{ml}$ ) in Group I \& II respectively (Table 5).

\section{- Number of vessels affected:}

There was no statistically significant difference between the two groups as regard the number of affected vessels $(p=0.073)$ (Table 6).

\section{- The results of PCI, assessed by TIMI flow:}

There was statistically significant difference between the two groups as regard TIMI flow after PCI $(p=0.022)$ (Table 7).

\section{- Killip classification of the studied population:}

There was no statistically significant difference between the two groups as regard Killip Classification $(p=0.318)$ (Table 8).

\section{- Renal function:}

In Group I, the mean $\mathrm{Cr}$ cl was $26.35 \pm 2.18$ $\mathrm{ml} / \mathrm{min}$. The mean creatinine levels were $1.36 \pm 0.21$ 
$\mathrm{mg} / \mathrm{dl}$ on admission, $2.08 \pm 0.32 \mathrm{mg} / \mathrm{dl}$ at peak, and $1.55 \pm 0.21 \mathrm{mg} / \mathrm{dl}$ at discharge. In Group II, the mean $\mathrm{Cr}$ cl was $39.10 \pm 5.61 \mathrm{ml} / \mathrm{min}$. The mean creatinine levels were $1.06 \pm 0.20 \mathrm{mg} / \mathrm{dl}$ on admission, $1.79 \pm$ $0.32 \mathrm{mg} / \mathrm{dl}$ at peak, and $1.36 \pm 0.18 \mathrm{mg} / \mathrm{dl}$ at discharge. There was statistically significant difference between the two groups as regard $\mathrm{Cr}$ cl level $(p$ $<0.001)$, s.Cr level on admission $(p<0.001)$, peak s.Cr level $(p$.value $=0.010)$, and s.Cr level at discharge with $(p<0.004)$ (Table 9).

- The creatinine level among Group I patients changed with a statistically significant difference between on admission, at peak, and at discharge $(p=0.001)$. Among Group II patients, the creatinine level also changed in a statistically significant way $(p=0.001)$ (Table 10).

\section{- Hb level:}

In Group I, the mean Hb level $10.65 \pm 0.996$ $\mathrm{gm} / \mathrm{dl}$ while in Group II, mean Hb level 11.62 \pm $1.396 \mathrm{gm} / \mathrm{dl}$. There was a statistically significant difference between the two groups $(p=0.017)$ (Table 11).

\section{- Ejection fraction percentage:}

In Group I, the mean Ejection Fraction percentage (EF\%) was $40.18 \pm 7.40 \%$ while in Group II, mean ejection fraction percentage was $48.67 \pm$ $8.05 \%$. There was a statistically significant difference between the two groups regarding the ejection fraction percentage ( $p$ 0.002) (Table 12).

\section{- Creatinine clearance in relation to HB level:}

In 32 patients with anemia the mean $\mathrm{Cr} \mathrm{cl}$ level was $32.09 \pm 5.279 \mathrm{ml} / \mathrm{min}$ while in 6 patients with normal HB level mean $\mathrm{Cr}$ cl level was $40.33 \pm 7.511$ $\mathrm{ml} / \mathrm{min}$. There was a statistically significant difference between the two groups ( $p=0.009)$ (Table 13).

\section{- Creatinine clearance in relation to systolic func- tion:}

In 11 patients with normal systolic function the mean $\mathrm{Cr}$ cl level was $38.00 \pm 8.56 \mathrm{ml} / \mathrm{min}$ while in 27 patients with impaired systolic function mean $\mathrm{Cr}$ cl level was $31.52 \pm 6.71 \mathrm{ml} / \mathrm{min}$. There was a statistically significant difference between the two groups ( $p=0.040)$ (Table 14).

\section{- Correlation between AKI parameters with admis- sion $\mathrm{Hb}$ and Ejection fraction:}

There was a statistically significant correlation between $\mathrm{Cr} \mathrm{cl}, \mathrm{Hb}$ level and ejection fraction. Also, there was a statistically significant correlation between creatinine level and ejection fraction (Table 15) and Figs. (1-3).
- Table (16): Reveals that significant relation between $\mathrm{EF} \%$, time to reperfusion and prediction of outcome (AKI) (Table 16).

- The Receiver Operating Characteristics (ROC) analysis was performed to compare the performance and predictive accuracy of $\mathrm{EF} \%$, and $\mathrm{Hb}$ level for predicting AKI. The Areas Under the Curve (AUC) for EF\% and $\mathrm{Hb}$ level were 0.804, and 0.702 ( $p<0.001, p=0.035$, respectively).

The EF\% carried the highest sensitivity $81 \%$ in predicting AKI with cutoff value $>41$, compared with admission $\mathrm{Hb}$ level that showed sensitivity of $76 \%$ with cutoff value $>10$. The positive predictive value of EF\% and admission $\mathrm{Hb}$ level with respect to AKI was $25 \%$ and 38 respectively and The negative predictive value of EF\% and admission $\mathrm{Hb}$ level with respect to AKI was $22 \%$ and 36 respectively (Table 17) and Fig. (4).

Table (1): Socio-demographic characteristics of the studied patient groups.

\begin{tabular}{|c|c|c|c|c|c|}
\hline $\begin{array}{l}\text { Chara- } \\
\text { cteristics }\end{array}$ & $\begin{array}{c}\text { Group I } \\
(\mathrm{n}=17) \\
\mathrm{n}(\%)\end{array}$ & $\begin{array}{c}\text { Group II } \\
(\mathrm{n}=21) \\
\mathrm{n}(\%)\end{array}$ & $\begin{array}{c}\text { Total } \\
(n=38)\end{array}$ & $\begin{array}{l}\text { Sig. } \\
\text { test }\end{array}$ & $p$ \\
\hline $\begin{array}{l}\text { Age (in } \\
\text { years): } \\
\text { - Mean } \pm \\
\text { SD } \\
\text { - Range }\end{array}$ & $\begin{array}{l}70.65 \pm \\
10.36 \\
50-85\end{array}$ & $\begin{array}{l}57.43 \pm \\
12.09 \\
38-82\end{array}$ & $\begin{array}{l}63.34 \pm \\
13.031 \\
38-85\end{array}$ & $\begin{array}{l}t \\
3.568\end{array}$ & $0.001 *$ \\
\hline $\begin{array}{l}\text { Gender: } \\
\text { - Male } \\
\text { - Female }\end{array}$ & $\begin{array}{l}10(58.8 \%) \\
7 \quad(41.2 \%)\end{array}$ & $\begin{array}{l}16(76.2 \%) \\
5 \quad(23.8 \%)\end{array}$ & $\begin{array}{l}26(68.4 \%) \\
12(31.6 \%)\end{array}$ & $\begin{array}{l}x^{2} \\
1.311\end{array}$ & 0.252 \\
\hline
\end{tabular}

Table (2): Clinical characteristics of both study groups.

\begin{tabular}{lcccc}
\hline Characteristics & $\begin{array}{c}\text { Group I } \\
(\mathrm{n}=17) \\
\mathrm{n}(\%)\end{array}$ & $\begin{array}{c}\text { Group II } \\
(\mathrm{n}=21) \\
\mathrm{n}(\%)\end{array}$ & $\chi^{2}$ & $p$ \\
\hline Diabetes mellitus & $10(58.8 \%)$ & $10(47.6 \%)$ & 0.473 & 0.492 \\
Hypertension & $8(47.1 \%)$ & $10(47.6 \%)$ & 0.131 & 0.973 \\
Dyslipidemia & $10(58.8 \%)$ & $15(71.4 \%)$ & 0.663 & 0.415 \\
Obesity & $7(41.2 \%)$ & $12(57.1 \%)$ & 0.958 & 0.328 \\
${ }^{*}$ : Statistically significant. & & & \\
$\chi^{2}:$ Chi square test.
\end{tabular}

Table (3): Smoking, addiction, and prior MI in both study groups.

\begin{tabular}{|c|c|c|c|c|}
\hline Characteristics & $\begin{array}{c}\text { Group I } \\
(\mathrm{n}=17) \\
\mathrm{n}(\%)\end{array}$ & $\begin{array}{c}\text { Group II } \\
(\mathrm{n}=21) \\
\mathrm{n}(\%)\end{array}$ & $x^{2}$ & $p$ \\
\hline Smoking & $9(52.9 \%)$ & $12(57.1 \%)$ & 0.67 & 0.796 \\
\hline Addiction & $1(5.9 \%)$ & $5 \quad(23.8 \%)$ & 2.271 & 0.132 \\
\hline Prior MI & $6(35.3 \%)$ & $2 \quad(9.5 \%)$ & 3.754 & $0.05^{*}$ \\
\hline
\end{tabular}


Table (4): Site of infarction among both study group patients.

\begin{tabular}{|c|c|c|c|c|}
\hline Characteristics & $\begin{array}{c}\text { Group I } \\
(\mathrm{n}=17) \\
\mathrm{n}(\%)\end{array}$ & $\begin{array}{c}\text { Group II } \\
(\mathrm{n}=21) \\
\mathrm{n}(\%)\end{array}$ & $x^{2}$ & $p$ \\
\hline $\begin{array}{l}\text { - Anterior. } \\
\text { - Inferior. } \\
\text { - Multiple. } \\
\text { - Anterior, posterior. } \\
\text { - Anterior, right. } \\
\text { - Anterior, posterior, } \\
\text { right, lateral. }\end{array}$ & $\begin{array}{ll}3 & (17.7 \%) \\
10 & (58.8 \%) \\
4 & (23.5 \%) \\
2 & (11.8 \%) \\
2 & (11.8 \%) \\
0 & (0 \%)\end{array}$ & $\begin{array}{ll}5 & (23.8 \%) \\
13 & (61.9 \%) \\
3 & (14.3 \%) \\
1 & (4.7 \%) \\
1 & (4.7 \%) \\
1 & (4.7 \%)\end{array}$ & 2.075 & 0.557 \\
\hline
\end{tabular}

Table (5): Time to reperfusion and contrast volume in both study group patients.

\begin{tabular}{lcccc}
\hline & $\begin{array}{c}\text { Group I } \\
(\mathrm{n}=17)\end{array}$ & $\begin{array}{c}\text { Group II } \\
(\mathrm{n}=21)\end{array}$ & $t$ & $p$ \\
\hline - Time to reperfusion & $67.94 \pm 26.04$ & $57.14 \pm 24.11$ & 1.313 & 0.198 \\
$\begin{array}{l}\text { (in minutes). } \\
\text { - Contrast volume. }\end{array}$ & $288.24 \pm 33.21$ & $285.71 \pm 82.37$ & 0.128 & 0.899 \\
\hline
\end{tabular}

$t: t$ for independent $t$-test.

Table (6): Number of affected vessels in both study group patients.

\begin{tabular}{|c|c|c|c|c|}
\hline Characteristics & $\begin{array}{c}\text { Group I } \\
(\mathrm{n}=17) \\
\mathrm{n}(\%)\end{array}$ & $\begin{array}{c}\text { Group II } \\
(\mathrm{n}=21) \\
\mathrm{n}(\%)\end{array}$ & $x^{2}$ & $p$ \\
\hline One vessel & $6(35.2 \%)$ & $12(57.2 \%)$ & 5.233 & 0.073 \\
\hline Two vessel & $4(23.5 \%)$ & $7 \quad(33.3 \%)$ & & \\
\hline Three vessel & $7(41.3 \%)$ & $2 \quad(9.5 \%)$ & & \\
\hline
\end{tabular}

*: Statistically significant.

$\chi^{2}:$ Chi square test.

Table (7): TIMI flow after PCI in both study group patients.

\begin{tabular}{lcccc}
\hline Characteristics & $\begin{array}{c}\text { Group I } \\
(\mathrm{n}=17) \\
\mathrm{n}(\%)\end{array}$ & $\begin{array}{c}\text { Group II } \\
(\mathrm{n}=21) \\
\mathrm{n}(\%)\end{array}$ & $\chi^{2}$ & $p$ \\
\hline II & $7(41.2 \%)$ & $2(9.5 \%)$ & 5.208 & $0.022 *$ \\
III & $10(58.8 \%)$ & $19(90.5 \%)$ & & \\
\hline *: Statistically significant. & \multicolumn{2}{c}{$\chi^{2}$ : Chi square test. }
\end{tabular}

Table (8): Killip classification for the studied population.

\begin{tabular}{|c|c|c|c|c|}
\hline Characteristics & $\begin{array}{c}\text { Group I } \\
(\mathrm{n}=17) \\
\mathrm{n}(\%)\end{array}$ & $\begin{array}{c}\text { Group II } \\
(\mathrm{n}=21) \\
\mathrm{n}(\%)\end{array}$ & $x^{2}$ & $p$ \\
\hline I & $11(64.7 \%)$ & $18(85.7 \%)$ & 2.294 & 0.318 \\
\hline II & $4 \quad(23.5 \%)$ & $2 \quad(9.5 \%)$ & & \\
\hline III & $2 \quad(11.8 \%)$ & $19(90.5 \%)$ & & \\
\hline
\end{tabular}

*: Statistically significant.

$\chi^{2}$ : Chi square test.

Table (9): Renal function in both study group patients.

\begin{tabular}{lcccc}
\hline Characteristics & $\begin{array}{c}\text { Group I } \\
(\mathrm{n}=17) \\
\text { Mean } \pm \mathrm{SD}\end{array}$ & $\begin{array}{c}\text { Group II } \\
(\mathrm{n}=21) \\
\text { Mean } \pm \mathrm{SD}\end{array}$ & $t$ & $p$ \\
\hline $\begin{array}{l}\text { - Creatinine } \\
\text { clearance (ml/min) }\end{array}$ & $26.35 \pm 2.18$ & $39.10 \pm 5.61$ & -8.821 & $0.001^{*}$ \\
$\begin{array}{l}\text { Creatinine level } \\
\text { (mg/dl): }\end{array}$ & & & & \\
- On admission. & $1.36 \pm 0.21$ & $1.06 \pm 0.20$ & 4.603 & $0.001^{*}$ \\
- Peak. & $2.08 \pm 0.32$ & $1.79 \pm 0.32$ & 2.726 & $0.010^{*}$ \\
- At discharge. & $1.55 \pm 0.21$ & $1.36 \pm 0.18$ & 3.142 & $0.004^{*}$ \\
\hline
\end{tabular}

$t: t$ for independent $t$-test.

*: Statistically significant.
Table (10): Follow-up of the creatinine level among both study groups.

\begin{tabular}{|c|c|c|c|c|}
\hline \multicolumn{3}{|c|}{ Creatinine level (mg/dl) } & \multirow[b]{2}{*}{$\mathrm{F}$} & \multirow[b]{2}{*}{$p$} \\
\hline $\begin{array}{c}\text { On } \\
\text { admission }\end{array}$ & Peak & $\begin{array}{c}\text { At } \\
\text { discharge }\end{array}$ & & \\
\hline
\end{tabular}

Group I:

Mean \pm SD $\quad 1.36 \pm 0.21 \quad 2.08 \pm 0.32 \quad 1.55 \pm 0.21 \quad 37.337 \quad 0.001^{*}$

Group II:

$\begin{array}{llllll}\text { Mean } \pm \text { SD } & 1.06 \pm 0.20 & 1.79 \pm 0.32 & 1.36 \pm 0.18 & 45.643 & 0.001 *\end{array}$ F: ANOVA (Analysis of Variance).

*: Statistically significant.

Table (11): Admission HB level in both study groups.

\begin{tabular}{lcccc}
\hline Admission $\mathrm{Hb}$ & $\begin{array}{c}\text { Group I } \\
(\mathrm{n}=17)\end{array}$ & $\begin{array}{c}\text { Group II } \\
(\mathrm{n}=21)\end{array}$ & $t$ & $p$ \\
\hline Mean $\pm \mathrm{SD}$ & $10.65 \pm 0.996$ & $11.62 \pm 1.396$ & -2.50 & $0.017^{*}$ \\
\hline$t: t$ for independent $t$-test. & & & \\
$*$ & $:$ Statistically significant.
\end{tabular}

Table (12): Ejection fraction \% in both study groups.

\begin{tabular}{lcccc}
\hline $\begin{array}{l}\text { Ejection } \\
\text { fraction } \%\end{array}$ & $\begin{array}{c}\text { Group I } \\
(\mathrm{n}=17)\end{array}$ & $\begin{array}{c}\text { Group II } \\
(\mathrm{n}=21)\end{array}$ & $t$ & $p$ \\
\hline Mean $\pm \mathrm{SD}$ & $40.18 \pm 7.40$ & $48.67 \pm 8.05$ & -3.381 & $0.002^{*}$ \\
\hline$t: t$ for independent $t$-test. & & & \\
$*$ & Statistically significant.
\end{tabular}

Table (13): Creatinine clearance in relation to HB level.

\begin{tabular}{lcccc}
\hline $\begin{array}{l}\text { Creatinine } \\
\text { clearance } \\
(\mathrm{ml} / \mathrm{min})\end{array}$ & $\begin{array}{c}\text { Patients with } \\
\text { Anemia } \\
(\mathrm{n}=32)\end{array}$ & $\begin{array}{c}\text { Patients with } \\
\text { normal HB } \\
(\mathrm{n}=6)\end{array}$ & $t$ & $p$ \\
\hline Mean $\pm \mathrm{SD}$ & $32.09 \pm 5.279$ & $40.33 \pm 7.511$ & -3.255 & $0.009^{*}$
\end{tabular}

$t: t$ for independent $t$-test.

* : Statistically significant.

Table (14): Creatinine clearance in relation to systolic function.

\begin{tabular}{lcccc}
\hline $\begin{array}{l}\text { Creatinine } \\
\text { clearance } \\
(\mathrm{ml} / \mathrm{min})\end{array}$ & $\begin{array}{c}\text { Normal Systolic } \\
\text { Function Ej\% } \\
\geq 50 \%(\mathrm{n}=11)\end{array}$ & $\begin{array}{c}\text { Abnormal Systolic } \\
\text { Function Ej } \\
<50 \%(\mathrm{n}=27)\end{array}$ & $t$ & $p$ \\
\hline Mean $\pm \mathrm{SD}$ & $38.00 \pm 8.56$ & $31.52 \pm 6.71$ & $2.2470 .040^{*}$ \\
\hline
\end{tabular}

Table (15 ): Correlation between AKI parameters with admission $\mathrm{Hb}$ and ejection fraction.

\begin{tabular}{lcc}
\hline Correlations & $r$. & $p$ \\
\hline Creatinine clearance $(\mathrm{ml} / \mathrm{min}):$ & & \\
$\quad$ Hb level & 0.412 & $0.01^{*}$ \\
Ejection fraction \% & 0.513 & $0.001^{*}$ \\
Creatinine level $(\mathrm{mg} / \mathrm{ml}):$ & & \\
Hb level & -0.063 & 0.708 \\
$\quad$ Ejection fraction \% & -0.463 & $0.003^{*}$ \\
\hline
\end{tabular}

$r$ : Pearson correlation coefficient. 
Table (16): Multivariate analysis logistic regression for AKI.

\begin{tabular}{|c|c|c|c|c|c|c|}
\hline & \multirow{2}{*}{ B } & \multirow{2}{*}{ SE } & \multirow{2}{*}{ Sig. } & \multirow{2}{*}{ OR } & \multicolumn{2}{|c|}{$95 \% \mathrm{CI}$} \\
\hline & & & & & LL & UL \\
\hline - EF \%. & -0.265 & 0.132 & $0.045^{*}:$ & 0.767 & 0.592 & 0.994 \\
\hline • Hb level. & -1.259 & 0.686 & 0.066 & 0.284 & 0.074 & 1.089 \\
\hline • Age. & 0.102 & 0.058 & 0.080 & 1.107 & 0.988 & 1.241 \\
\hline $\begin{array}{l}\text { Time to } \\
\text { reperfusion. }\end{array}$ & -0.054 & 0.038 & 0.150 & 0.947 & 0.880 & 1.020 \\
\hline $\begin{array}{l}\text { - TIMI flow after } \\
\text { procedure. }\end{array}$ & 3.310 & 1.647 & $0.044^{*}$ & 27.374 & 1.085 & 90.426 \\
\hline - Prior MI. & -0.503 & 1.503 & 0.738 & 0.605 & 0.032 & 11.508 \\
\hline $\begin{array}{l}\text { B : Un standard } \\
\text { SE : Standard Err } \\
\text { OR : Odds Ratio. }\end{array}$ & & & & $\begin{array}{l}\text { II : Conf } \\
\text { L : Low } \\
\text { JL : Uppe }\end{array}$ & $\begin{array}{l}\text { idence } \\
\text { id Limit } \\
\text { r Limit }\end{array}$ & \\
\hline
\end{tabular}
L

Table (17): Agreement (sensitivity, specificity and accuracy) for $\mathrm{EF} \%$, and $\mathrm{HB}$ level with severity of AKI.

\begin{tabular}{lccccccc}
\hline & \multirow{2}{*}{ Cutoff AUC } & \multirow{2}{*}{$p$} & \multicolumn{3}{c}{ Sensi- } \\
tivity & \multicolumn{3}{l}{ Speci- PPV } & \multirow{2}{*}{ ficity } & NPV \\
\hline EF\% & 41.0 & 0.804 & $0.001^{*}$ & 81.0 & 70.6 & 25.0 & 22.7 \\
Admission HB & 10.5 & 0.702 & $0.035^{*}$ & 76.2 & 47.1 & 38.5 & 36.0 \\
\hline
\end{tabular}

AUC : Area Under the Curve.

PPV : Positive Predictive Value.

NPV : Negative Predictive Value.

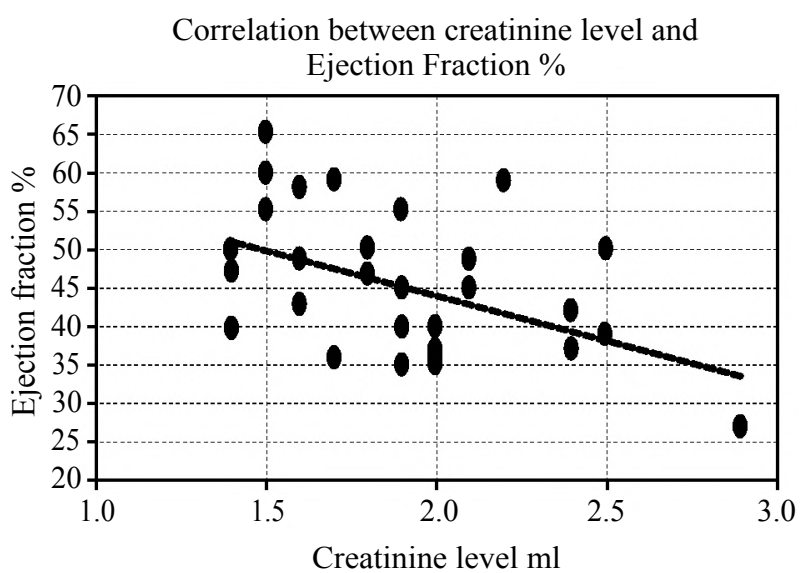

Fig. (1): Correlation between creatinine level and ejection fraction.

Correlation between creatinine clearance and HB level

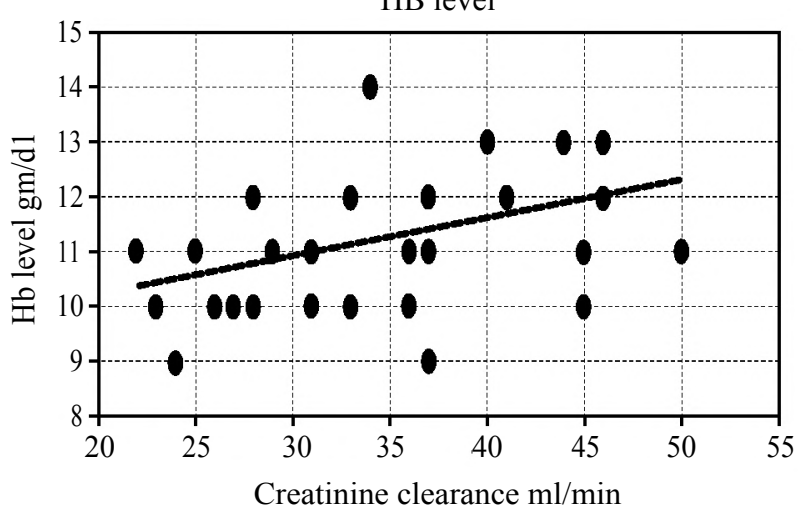

Fig. (2): Correlation between $\mathrm{Cr} \mathrm{cl}$ anf $\mathrm{Hb}$ level.

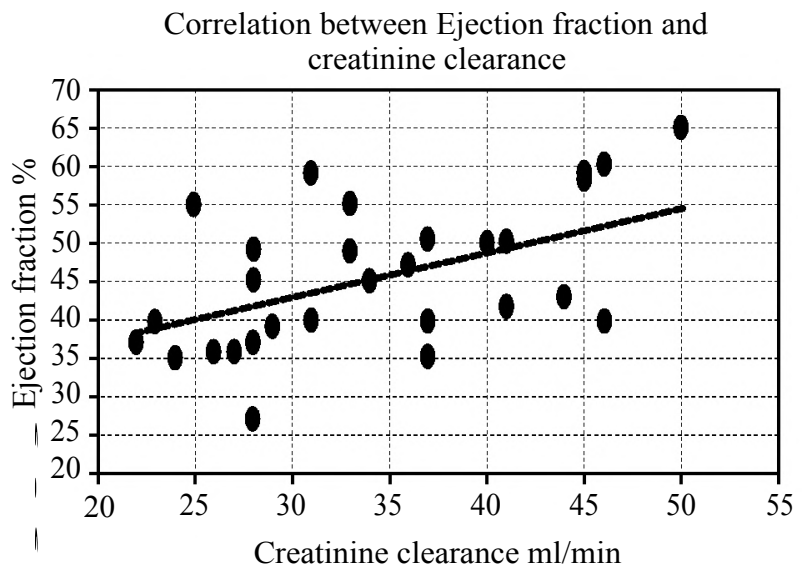

iig. (3): Correlation between ejection fraction and $\mathrm{Cr} \mathrm{cl}$.

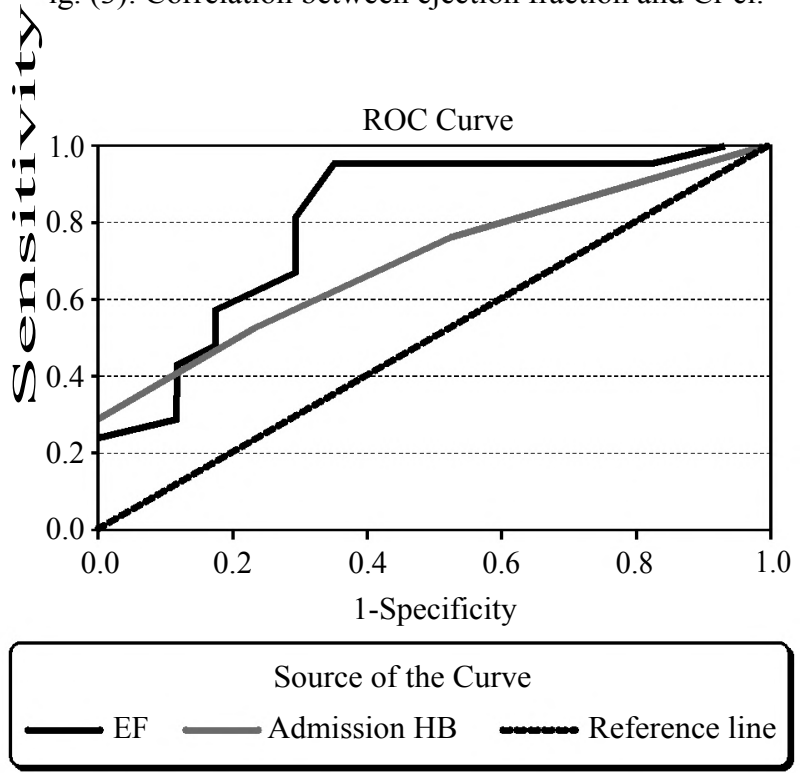

Fig. (4): ROC curve for sensitivity and specificity.

\section{Discussion}

Acute kidney injury is a common and a serious complication of primary PCI after STEMI that affects both mortality and morbidity and affects outcome of the procedure and can be the cause of death and MACE rather than STEMI complications itself. Patients who develop CIN have a 5.5 fold increased risk of death when compared to the patients without CIN [19].

In 2014, the European Society of Cardiology published updated guidelines on CIN prevention which provides a framework for the use of evidence-based strategies for prevention [20].

In the aim of prevention of occurrence, contrast induced nephropathy after primary PCI risk factors and predictors should be properly identified and well understood so that preventive measures and precautions could be applied. 
Many predictive risk scores were developed to estimate risk of CIN as Mehran risk score developed by Mehran et al., [21] in 2004. Based on the attained score, patients were further divided into low, moderate, high, very high risk groups, and the incidence of CIN, risk of dialysis and mortality are calculated for each group, also the ACEF score (age, creatnine clearance and ejection fraction) is proved as useful score for CIN prediction by Giuseppe et al., [22]

Novel risk prediction algorithm using computational tool proposed by Gurm et al., [23] may prove useful for both bedside clinical decision making and risk assessment.

In the present study we aim to correlate baseline patient characteristics and initial clinical evaluation at presentation with prevelance and severity of AKI.

As regard age: In Group I a higher mean age (70.65 \pm 10.36$)$ was observed while in Group II younger ages were more prevalent with significant correlation of age with prevalence and severity of AKI.

Similarly in 2015 Taku et al., [24] in their study that aimed at the development and validation of a pre-PCI risk model for CIN prediction and included 358 patients who developed CIN in a COHORT study showed that those patients tend to be older with mean age $72.1 \pm 12.1$ [24]

With concordance with the present study also a prospective observational study carried out by Eleni et al., [25] suggested that critically ill patients aged 65 or more years old are more prone to present with renal injury after the intravenous infusion of radiocontrast media compared to patients aged less than 65 years old even with normal baseline renal function [25].

As regard sex, the present study couldn't find any significant difference in gender either in prevalence or severity of AKI.

In controversy with our study, the study by Taku et al., [24] also demonstrated CIN is commoner among female gender in their study [24]

There is a lack of data regarding CIN and gender association. Despite discordant and inconsistent data, a large study suggested female sex as an independent risk factor for CIN. Various characteristics related to female sex such as advanced age at the time of presenting with STEMI, comorbidities and reduced body surface might increase the risk of CIN [26]
In the present study smoking and addiction were not found to have any statistical significant relation with the risk of developing AKI.

Similarly Mehran et al., [21] in their study conducted on 891 patients to validate Mehran risk score for prediction of CIN demonstrated that smoking and ex-smoking was not correlated to the risk of developing renal impairment after primary PCI.

As regard diabetes mellitus, the present study showed that there is no correlation between DM and AKI with no difference among the group with severe renal impairment compared to the group who developed mild to moderate impairment.

On the contrary, in a study carried on Italian patients by Salvatore Evola et al., [27] to assess risk factors of CIN $42 \%$ of 105 patients were found diabetics with $p$.value $=0.03$ in comparison with those who did not develop AKI.

As regard hypertension, the present study showed that there is no correlation between hypertension and AKI with no difference among the group with severe renal impairment compared to the group who developed mild to moderate impairment. There was no statistical significant relation with the risk of developing AKI with ( $p$.value= 0.973).

On the contrary, Salvatore et al., [28] in their study also demonstrated arterial hypertension as strong independent risk predictor for CIN with $80 \%$ prevalence among their CIN group and $p<$ 0.05 . This difference may be due to few number of patients in the present study.

As regard dyslipidemia, the present study cannot find any significant correlation between dyslipidemia and incidence or severity of AKI.

Similarly in the previously mentioned study conducted by Alberto et al., [29] hypercholesterolemia was found to have no significant correlation with contrast induced nephropathy in their affected population 33\% had hypercholesterolemia.

As regard previous history of prior MI, the present study correlated presence of prior MI as a predictor for AKI occurrence with more prevalence among the group with severe renal impairment with $(p<0.05)$ compared to the group who developed mild to moderate impairment.

In the present study, contrast volume was not found to have any statistical significant relation with the risk of developing AKI, in Group I the 
volume was $288.24 \pm 33.21 \mathrm{ml}$ and in Group II it was $285.71 \pm 82.37 \mathrm{ml}$ with $(p=0.899)$.

Similarly, data on contrast volume used were available in only 418 (38 had AKI) patients, however, its amount during PCI did not differ between patients with or without AKI (134-49ml vs 147$47 \mathrm{ml}$, respectively; $p-0.136)$, or in multivariate models [30].

As regard TIMI flow after PCI, the present study showed that less TIMI flow is more prevalent among the group with severe renal impairment with $(p=0.022)$ compared to the group who developed mild to moderate impairment.

As regard change in creatinine level, the study showed that higher creatinine level in the group with severe renal impairment with mean \pm SD $1.36 \pm 0.21$ on admission, $2.08 \pm 0.32$ peak and $1.55 \pm$ $0.21 \mathrm{SD}$ at discharge with $(p=0.001)$ compared to the other group who developed mild to moderate impairement mean \pm SD level was $1.06 \pm 0.20$ on admission, $1.79 \pm 0.32$ peak and $1.36 \pm 0.18 \mathrm{gm} / \mathrm{dl}$ at discharge with $(p=0.001)$.

As regard hemoglobin level, in this present study, it was significantly correlated to incidence of AKI where anemic patients had more risk of developing renal impairment and it tends to be more severe $(p=0.017)$.

In concordance with the present study, another retrospective, single-centre observational study at the Tel-Aviv Sourasky Medical Center, a tertiary referral hospital with a 24/7 PPCI service by Shacham et al., [30] found that patients with AKI had significantly lower admission hemoglobin levels $(13.6-1.7 \mathrm{~g} / \mathrm{dL}$ vs $14.4-1.5 \mathrm{~g} / \mathrm{dL} ; p<0.001)$ and were more likely to be anemic ( $27 \%$ vs $12 \% ; p<0.001)$.

The prevalence of AKI in anemic patients was two fold higher than in non anemic patients (37\% vs $19 \% ; p-0.001)$, yet there was a substantially lower AKI prevalence compared with patients with reduced baseline kidney function.

In a multivariate logistic regression model, a lower admission hemoglobin level (Odds Ratio [OR], 0.86; 95\% Confidence Interval [CI], 0.74$0.98 ; p-0.04)$ and anemia at admission (OR, 1.76; $95 \%$ CI, 1.02-3.02; $p$-0.04) emerged as independent predictors of AKI [30]

It is reported that contrast media could increase oxygen affinity of hemoglobin, so oxygen delivery to the peripheral tissues might be impaired. Local renal hypoxia can be more aggravated in patients with low hemoglobin after exposure to contrast media; hence, the combination of contrast-induced vasoconstriction and anemia may decrease oxygen delivery sufficiently to cause renal medullary hypoxia. Thus, it is intuitive that anemia may play a role in CIN risk [31]

Regarding left ventricular function, the present study showed that $48 \%$ of the study population had LV ejection fraction less than $50 \%$ with more prevalence of these myopathic patients among the Group I members who developed severe renal impairment, ( LV EF $<50 \%$, with a mean \pm SD EF of $40.18 \pm 7.40$.

In a similar study performed by Yacov Shacham et al., [32] to assess the association of left ventricular function and acute kidney injury among STIMI patients treated by primary percutaneous intervention, a retrospective, single center observational study at the Tel-Aviv Sourasky Medical Center, a tertiary referral hospital with a $24 / 7$ primary PCI service, 34 patients admitted from June 2011 to December 2013 to the cardiac Intensive Care Unit with the diagnosis of acute STEMI, underwent primary PCI and developed CIN were enrolled [32]. The patients were found to be older, to have more co-morbidities, longer time to reperfusion. In this cohort of patients with STEMI who underwent PCI, the occurrence of AKI after primary PCI was associated with worse LV systolic and diastolic function; however, only LVEF emerged as an independent predictor of AKI. For every $1 \%$ reduction in $\mathrm{EF}$, the risk of $\mathrm{AKI}$ increased (odds ratio $1.1,95 \%$ confidence interval 0.86 to 0.96 , $p$.value 0.001 [32].

The sudden myocardial insult in STEMI results in an acute reduction of the LV pumping function, and this leads to reduced effective renal blood flow, consequently causing hypoxic change and the synthesis of reactive oxygen species. In addition the increased sympathetic tone, renin angiotensinaldosterone system activation, the overproduction of many humoral factors such as vasopressin, catecholamines, endothelin, proinflammatory cytokines, and decreased nitric oxide levels can cause vascular endothelial cell damage, further aggravating blood flow disturbances and making the kidney more susceptible to CIN [32].

\section{Conclusion:}

AKI could be a serious outcome complicating primary PCI for STEMI patients affecting both morbidity and mortality and the incidence of AKI is greatly affected by many risk factors. Preprocedural risk factors and clinical status are the most important and common predictors of devel- 
oping renal impairment post contrast medium exposure.

In this study our patients are evaluated preprocedurally and risk factor are well assessed then s. Cr and $\mathrm{Cr} \mathrm{cl}$ are observed post-procedure for identifying patients with AKI as defined before. Findings in clinical evaluations and patient's characteristics and baseline risk factor are then correlated to the risk of developing AKI and its severity.

Older ages, previous history of myocardial infarction, TIMI flow after PCI, anemia on admission, level of serum creatinine on admission, creatinine clearance and impaired systolic function of left ventricle were strongly statistically different with developing AKI and to its severity. While no significant statistical difference could be found as regard gender, smoking, addiction, diabetes, dyslipidemia, Killip classification, time to reperfusion, or site of infarction with incidence of developing AKI.

\section{References}

1- STEG P.G., JAMES S.K., ATAR D., BADANO L.P., BLOMSTOM-LUNDQVIST C., et al.: ESC Guidelines for the management of acute myocardial infarction in patients presenting with ST-segment elevation. Eur. Heart J. October; 33 (20): 2569-619, 2012.

2- O'GARA P.T., KUSHNER F.G., ASCHEIM D.D., CASEY D.E., CHUNG M.K., De LEMOS J.A., et al.: 2013 ACCF/AHA guideline for the management of ST-elevation myocardial infarction: executive summary: A report of the American College of Cardiology Foundation/American Heart Association Task Force on Practice Guidelines. Circulation; 127: 529-55, 2013.

3- SHACHAM Y., LESHEM-RUBINOW E., STEINVIL A., ASSA E.B., KEREN G., ROTH A., et al.: Renal impairment according to acute kidney injury network criteria among ST elevation myocardial infarction patients undergoing primary percutaneous intervention: A retrospective observational study. Clin. Res. Cardiol.; 103. doi: 10.1007/ s00392-014-0680-8, 2014.

4- GOLDBERG A., HAMMERMAN H., PETCHERSKI S., ZDOROVYAK A., YALONETSKY S., KAPELIOVICH M., et al.: Inhospital and 1-year mortality of patients who develop worsening renal function following acute STelevation myocardial infarction. Am. Heart J.; 150: 3307, 2005.

5- PARIKH C.R., COCA S.G., WANG Y., MASOUDI F.A. and KRUMHOLZ H.M.: Long-term prognosis of acute kidney injury after acute myocardial infarction. Arch. Intern. Med.; 168: 987-95, 2008.

6- AMIN A.P., SPERTUS J.A., REID K.J., LAN X., BUCHANAN D.M., DECKER C., et al.: The prognostic importance of worsening renal function during an acute myocardial infarction on long-term mortality. Am. Heart J.; 160: 1065-71, 2010.
7- TSAI H.S., CHEN Y.C. and CHU P.H.: The Influence of Acute Kidney Injury on Acute Cardiovascular Disease. Acta. Cardiol. Sin.; 30: 93-7, 2014.

8- GIANCARLO MARENZI, ASSANELLI E., CAMPODONICO J., LAURI G., MARANA I., METRIO M. De, et al.: Contrast vollume during primary percutaneous coronary intervention and subsquent contrast-induced nephropathy and mortality. Ann. Intern. Med.; 150: 1707, 2009 .

9- MARENZI G., De METRIO M., RUBINO M., LAURI G., CAVALLERO A., ASSANELLI E., et al.: Acute hyperglycemia and contrast-induced nephropathy in primary percutaneous coronary intervention. Am. Hear. J.; 160: 1170-7, 2010.

10- NIKOLSKY E., MEHRAN R., TURCOT D., AYMONG E.D., MINTZ G.S., LASIC Z., et al.: Impact of chronic kidney disease on prognosis of patients with diabetes mellitus treated with percutaneous coronary intervention. Am. J. Cardiol.; 94: 300-5, 2004.

11- PANNU N., WIEBE N. and TONELLI M.: Prophylaxis strategies for contrast-induced nephropathy. J.A.M.A.; 295: 2765-79, 2006.

12- BARRETT B.J. and PARFREY P.S.: Preventing Nephropathy Induced by Contrast Medium. N. Engl. J. Med.; 354: 379-86, 2006.

13- NIKOLSKY E., AYMONG E.D., HALKIN A., GRINES C.L., COX D.A., GARCIA E., et al.: Impact of anemia in patients with acute myocardial infarction undergoing primary percutaneous coronary intervention. J. Am. Coll. Cardiol.; 44: 547-53, 2004.

14- SABATINE M.S., MORROW D.A., GIUGLIANO R.P., BURTON P.B., MURPHY S.A., McCABE C.H., et al.: Association of hemoglobin levels with clinical outcomes in acute coronary syndromes. Circulation; 111: 2042-9, 2005.

15- DUNDAR C., ODUNCU V., ERKOL A., TANALP A.C., SIRMA D., KARAGOZ A., et al.: In-hospital prognostic value of hemoglobin levels on admission in patients with acute ST segment elevation myocardial infarction undergoing primary angioplasty. Clin. Res. Cardiol.; 101: 37 44, 2012.

16- ASTOR B., MUNTNER P., LEVIN A., EUSTACE J. and CORESH J.: Association of kidney function with anemia: The Third National Health and Nutrition Examination Survey (1988-1994). Arch. Intern. Med.; 162: 1401-8, 2002.

17- Nutritional anaemias. Report of a WHO scientific group. World Health Organ Tech. Rep. Ser.; 405: 5-37, 1968.

18- COCKCROFT D.W. and GAULT M.H.: Prediction of creatinine clearance from serum creatinine. Nephron; 16 (1): $31-41,1976$.

19- AUTHORS/TASK FORCE MEMBERS, WINDECKER S., KOLH P., ALFONSO F., COLLET J.P., CREMER J., et al.: 2014 ESC/EACTS Guidelines on myocardial revascularization. Eur. Heart J.; 35: 2541-619, 2014.

20- REAR R., BELL R.M. and HAUSENLOY D.J.: Contrastinduced nephropathy following angiography and cardiac interventions. Heart; 102: 638-48, 2016.

21- MEHRAN R., AYMONG E.D., NIKOLSKY E., LASIC Z., IAKOVOU I., FAHY M., et al.: A simple risk score 
for prediction of contrast-induced nephropathy after percutaneous coronary intervention. J. Am. Coll Cardiol.; 44: 1393-9, 2004.

22- CHANG C.H., LEE C.C., CHEN S.W., FAN P.C., CHEN Y.C., CHANG S.W., et al.: Predicting Acute Kidney Injury Following Mitral Valve Repair. Int. J. Med. Sci.; 13: 1924, 2016.

23- GURM H.S., SETH M., KOOIMAN J. and SHARE D.: A Novel Tool for Reliable and Accurate Prediction of Renal Complications in Patients Undergoing Percutaneous Coronary Intervention. J. Am. Coll. Cardiol.; 61: 22428, 2013.

24- INOHARA T., KOHSAKA S., ABE T., MIYATA H., NUMASAWA Y., UEDA I., et al.: Development and Validation of a Pre-Percutaneous Coronary Intervention Risk Model of Contrast-Induced Acute Kidney Injury With an Integer Scoring System. Am. J. Cardiol.; 115: 1636-42, 2015.

25- PALLI E., MAKRIS D., PAPANIKOLAOU J., GAROUFALIS G. and ZAKYNTHINOS E.: Contrast-Induced Nephropathy in Aged Critically Ill Patients. Oxid. Med. Cell. Longev.; 2014: 1-6, 2014.

26- AURELIO A. and DURANTE A.: Contrast-Induced Nephropathy in Percutaneous Coronary Interventions: Pathogenesis, Risk Factors, Outcome, Prevention and Treatment. Cardiology; 128: 62-72, 2014.

27- EVOLA S., LUNETTA M., MACAIONE F., FONTE G.,
MILANA G., CORRADO E., et al.: Risk factors for contrast induced nephropathy: A study among Italian patients. Indian Heart J.; 64: 484-91, 2012.

28- EVOLA S., LUNETTA M., MACAIONE F., FONTE G., MILANA G., CORRADO E., et al.: Risk factors for contrast induced nephropathy: A study among Italian patients. Indian Heart J.; 64: 484-91, 2012.

29- BOUZAS-MOSQUERA A., VÁZQUEZ-RODRÍGUEZ J.M., CALVIÑO-SANTOS R., PETEIRO-VÁZQUEZ J., FLORES-RÍOS X., MARZOA-RIVAS R., et al.: [Contrast-induced nephropathy and acute renal failure following emergent cardiac catheterization: Incidence, risk factors and prognosis]. Rev. Esp. Cardiol.; 60: 1026-34, 2007.

30- SHACHAM Y., LESHEM-RUBINOW E., GAL-OZ A., ARBEL Y., KEREN G., ROTH A., et al.: Relation of time to coronary reperfusion and the development of acute kidney injury after ST-segment elevation myocardial infarction. Am. J. Cardiol.; 114: 1131-5, 2014.

31- LI W., LI D., HAN F., XU T., ZHANG Y. and ZHU H.: Impact of anemia on contrast-induced nephropathy (CIN) in patients undergoing percutaneous coronary interventions. Int. Urol. Nephrol.; 45: 1065-70, 2013.

32- SHACHAM Y., LESHEM-RUBINOW E., GAL-OZ A., TOPILSKY Y., STEINVIL A., KEREN G., et al.: Association of left ventricular function and acute kidney injury among ST-elevation myocardial infarction patients treated by primary percutaneous intervention. Am. J. Cardiol.; 115: 293-7, 2015.

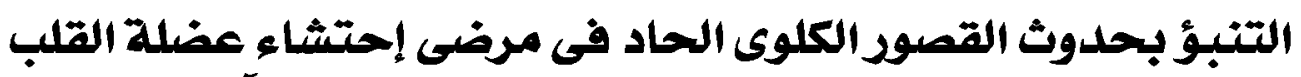

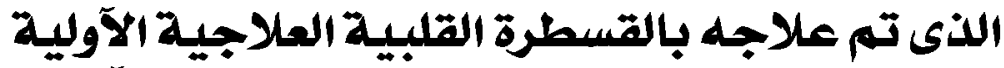

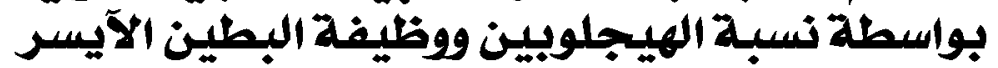

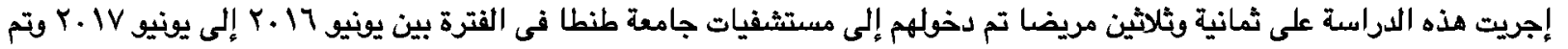

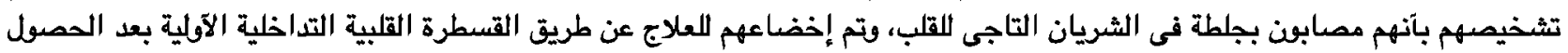

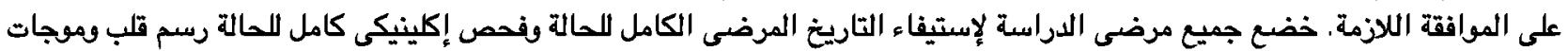

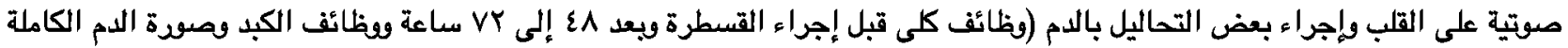 \\ ونسبة الدهون بالام، السكر العشوائي). \\ وتم تقسيم حالات الدراسة إلى مجموعتين تبعا لدرجة إعتلال الكلى الناتج وهما:

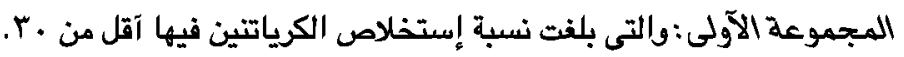

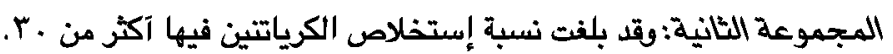 \\ وقد خلصت هذه الدراسة إلى آن كبار السن والمرضى نو تاريخ مرضى سابق لإحتشاء بعضلة القلب والمرضى الذين يعانوا من بطئ سريان

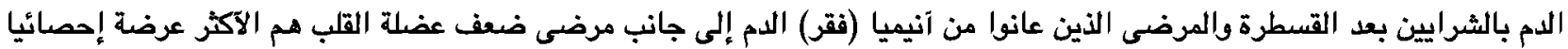 \\ لحدوث إعتلال فى وظائف الكلى بعد إستخدام الصبغة والهين. \\ وتبين من مذه الدراسة آيضا إلى آنه لم يوجد فروق ذات دلالة إحصائية بين مرضى المجموعتين فيما يتعلق بجنس المريض والتدخين \\ وإختلال نسبة الدهون بالام ومرضى السكرى.
}

